\title{
The Times They Are a-Changin'1 (again!): the second, great digital transition to the mobile space
}

\author{
David Nicholas \\ CIBER Research Ltd, UK, the University of Tennessee, USA, \\ Northumbria University, uK
}

\begin{abstract}
Purpose: According to industry estimates the mobile device will soon be the main platform for searching the web and reading the information found there, and yet our knowledge of how millions of mobile consumers use information, and how that differs from desktops/laptops users, is imperfect. The paper sets out to fill the knowledge gap.

Approach/methods: The method used is an analysis of the logs of a major cultural website, Europeana. The behavior of more than 150,000 mobile users was examined over a period of more than a year and compared with that for PC users of the same site and for the same period. The analyses conducted include: size and growth of use, time patterns of use; geographical location of users and, comparative information-seeking behaviour patterns.

Results and conclusions: The main findings were that mobile users were the fastest-growing user group and will rise in number very rapidly and that their visits were very different in the aggregate from those arising from fixed platforms. Mobile visits could be described as being information "lite": typically shorter, less interactive, and less content viewed per visit. Use takes a social rather than office pattern, with mobile use peaking at nights and weekends. The variation between different mobile devices was large, with information seeking on the iPad similar to that for PCS and laptops and that for smartphones very different indeed. The research further confirms that information seeking behavior is platform-specific and the latest platforms are changing it all again. Websites, publishers an dlibrarians will have to adapt.

Originality/Value: The research described here constitutes one of the biggest studies of mobile users published and certainly no one else has conducted research on cultural information consumers on the go.
\end{abstract}

Keywords Europeana. Log analysis. Information behaviour. Information searching. Mobile users. PC users.

Received: 28.07.2013. Revised: 12.10.2013. Accepted: 26.10.2013.

\section{Introduction}

Not so very long ago CIBER researchers shocked information professionals and publishers with revelations of what the Google Generation were up to in the virtual, unmediated digital information space (Rowlands et al., 2008). Information seeking there was fast, furious, abbreviated and promiscuous; bouncing and skittering were the preferred forms of

\footnotetext{
1 The title of a Bob Dylan album, made in 1964.
} 
behaviour; viewing was preferred to reading and nobody undertook advanced searching but everyone used Google. Follow-up work showed it was not just the Google Generation, but also virtual scholars, that were behaving in ways not quite what librarians and publishers had envisaged when designing their websites and databases (Nicholas \& Rowlands, 2010). The supposed orderly information seeking and deep reading behavior of the scholar had been transformed by the move to the digital world, the huge range of choices offered and the data storm unleashed. Fast bag pick-up (Grab a PDF and get out of the site quickly) and reading 'lite' are the order of the day as scholars developed new strategies for dealing with expanding choice and the unending data deluge.

However we probably have seen nothing yet, with publishers and librarians not having had time to catch breath and take stock of the first revolution - partly, perhaps, because many were in denial about the scale of change - another revolution is already on us, the mobile revolution; a revolution that is likely to be bigger than the first one. The mobile revolution constitutes another massive round of disintermediation and migration. More people have mobiles than computers and there are many more mobiles than computers. We are not so much talking about the mobile phone, which has now been with us forty years, but the smartphone and tablet. Americans are clearly leading the way with fifty-six percent of them now (2013) owning a smartphone (Pew Internet, 2013a) and thirty-four percent owning a tablet (Pew Internet, 2013b), and where the Americans have gone others will follow. According to communications industry estimates, if the mobile device is not already the main platform for searching the web, it probably will be next year (Eddy, 2013). The day when most information seeking and reading was undertaken via a PC in a library or office has long gone. For library and office read the train, coffee shop and kitchen table, we could not have travelled further from the original library-tethered online computer. And, as we shall learn, the change of environment and context inevitably changes the nature of searching and reading.

The Google Generation and the rest of the population (playing catch-up) have been empowered by a mobile device that will inevitably take a form of digital information seeking and using behaviour already regarded by some as dumbed down (Carr, 2011) to an unprecedented level of abbreviation and skittering and, as a consequence, may bury long prized scholarly institutions and belief systems with it. As a member of the audience at a conference in Tartu put it after hearing the author describe the behavior of the virtual scholar, 'this surely is the end of culture as we know it' (Nicholas, 2012). This is, of course, was an exaggeration, but only a slight one because big changes in the way we consume information are already afoot.

While the first transition, from the physical to digital, transformed the way we seek, read, trust and consume information, until relatively recently the environment and conditions in which scholars conducted these activities had not really changed - it was still largely in the library or office, sometimes the home.

However, with the second transition to the mobile environment, information behaviour is no longer mediated or conditioned by the office or library (and its rules and impositions), but by the street, coffee shop, home; in a nutshell by social norms. The mobile device is after all embedded in daily life. This means that information usage and seeking has not only moved environments, it has been time-shifted too. There are other significant differences which will inevitably lead to changes in the composition of the user population and their information seeking behaviour: 
(1) With mobile devices, people can meet their information needs at the very time of need, rather than cold store them until they reach the office, library or home. Logically this should mean that more needs are met, but, as we shall learn, perhaps not always that well. After all if you have to store them there is always the likelihood that they may be forgotten or overwritten by another need. So might we expect more visits and searches from mobile users overall, but less intensive visits?

(2) While library 'Big deals' provide fantastic access to information to a privileged few, those behind the walled gardens; the mobile device provides access to masses of information for everyone and anywhere; and, for scholars, open access publishing is busy increasing the haul;

(3) Mobiles are essentially social media devices and that means they stride the two major information domains, the informal and formal; publishers have been trying hard (but not really succeeding) to marry the two on their websites and perhaps the mobile device offers opportunities for them, but they are yet to grasp this;

(4) Mobiles are an intrinsic part of the digital consumer purchasing process - they are used to search for information prior to purchase, during the process itself and, of course, to make the purchase. We might then expect that scholars might be more likely to go down the pay per view route, or perhaps, they may not understand why they have to pay for information they mostly get for free;

(5) People appear to trust the mobile phone more than any other form of information and communication technology (Srivastava, 2005). Just as they trust Google. We have come a very long way in a very short period of time. It was not that long ago when libraries introduced bans on using phones on their premises. Now ask any young person (and growing numbers of not so young people) about their library and they will point to their smartphone. What an irony, the mobile has actually become the library!

(6) Clearly mobile devices have smaller screens and offer different ways of interacting with the device (via touch screens and voice recognition rather than keyboards, mice and pointers) and logically we would expect this to impact on usage.

It is very clear then that mobiles devices have a huge potential to draw in a larger audience for scholarly information, change the nature of information seeking behaviour and to do this for billions of people, yet despite the considerable challenges for all stakeholders in the scholarly communications market we know very little about a) how users behave in the mobile environment; b) how differently this behavior is from that associated with laptops and desktops.

This paper fills the gap in our knowledge with an analysis of the usage logs of Europeana, the interface to Europe's cultural digital culture. Europeana is a simple but powerful tool for finding cultural resources from all over Europe (Figure 1). Books, journals, films, maps, photos, music, videos and paintings are available for everyone to consult - and to use, copyright permitting. It is a site which currently attracts around five million visitors and is used heavily by humanities scholars, but also by French school children, and has a seasonal academic pattern of usage common to most publisher platforms. Europeana, with an eye on a strategic market for them, tourists, who are of course interested in culture and who could benefit considerably from information on the go, started considering the mobile user in its early development plans and since then has had to adapt its plans as a result of 
the rise of the tablet. Europeana has largely been successful in this and now (2013) boasts 155,000 mobile visitors, whose behaviour are the subject of this paper. Scholarly publishers can learn a lot from its users' experiences, as to can librarians.

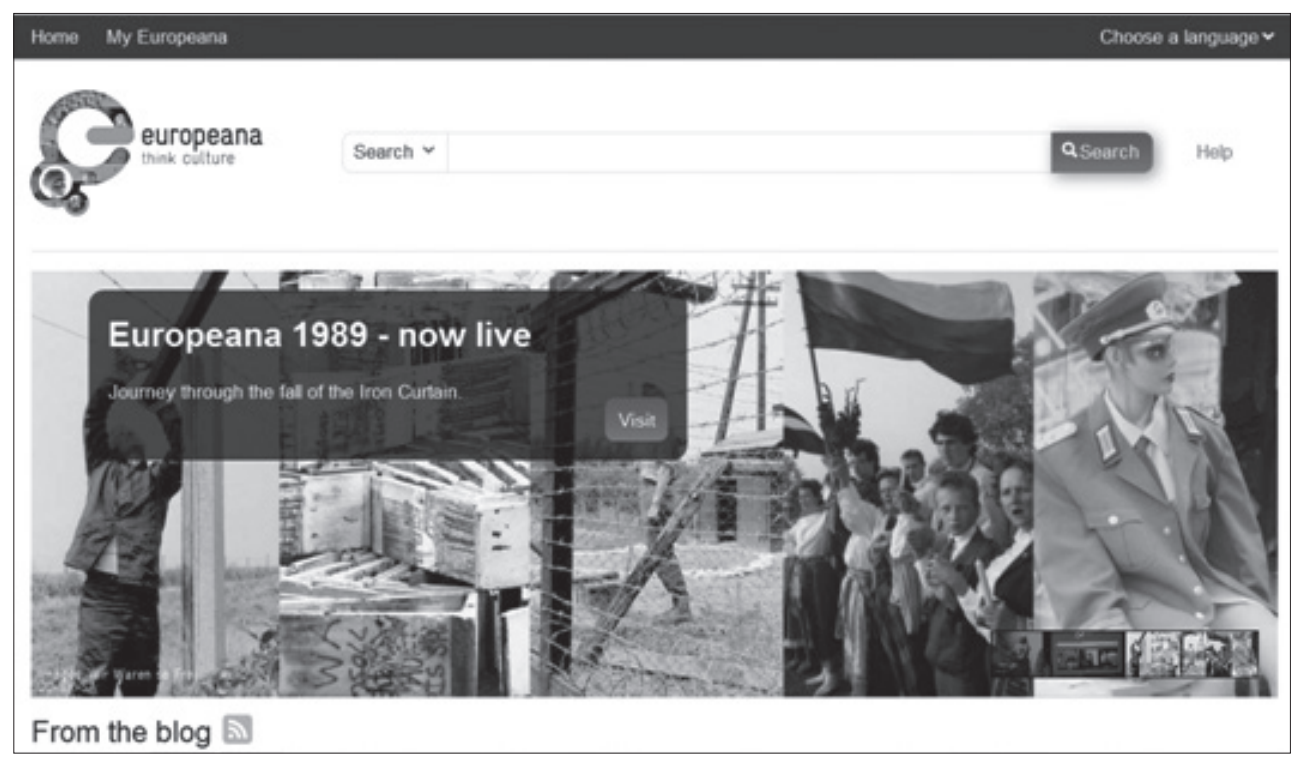

Figure 1. Europeana Home Page

\section{Methodology}

Log analysis techniques were employed to study users' interactions with the Europeana website. We studied how people actually seek, search, navigate, use and act upon information in the virtual space that is Europeana. When log analysis is used to provide very detailed, bespoke user-oriented analyses of digital services and sites, as it is in this study, we call it 'deep' log analysis to distinguish it from 'flat' log analyses of the kind produced by COUNTER and the somewhat deeper analyses obtained from Google Analytics. The log files included the usual log fields such as date, time, IP, referrer, and user-agent and SPSS was used for the analysis. These HTTP access logs were supplemented with data obtained Clickstream logs and Google Analytics, which had the added value of providing cookie information. More information on the techniques and comparisons of various methods of obtaining digital usage data can be found in a report by CIBER (CIBER, 2013) and in an article by Nicholas and Clark (Nicholas \& Clark, 2012).

The data analysed included three years of standard log files (October 2009 - December 2012). In all the dataset contained 200 million page views made by 8 million unique visitors. These data were supplemented by Google Analytic data since 2011. Various time windows are used in this paper to evaluate mobile behaviour and because of the fast changing (growing) mobile environment we tend to favour the most current time window. 


\section{Fundamental characteristics of digital information seeking behaviour}

The foundations of modern day digital information reading and seeking behaviour are already in place as a result of long exposure to desktops and laptops and it will be on this behaviour that mobile behaviour will build, so it is worth going over what we have learnt to date about digital behaviour:

(1) Digital users are hyperactive: they love the digital choices offered by the Internet, which makes them always looking for something or other. Thanks to the web, huge advances in connectivity (e.g. wireless) and open access policies virtually everyone is connected to the 'big fat information pipe' supplying information 24/7, 365 days a year and they certainly avail themselves of this facility;

(2) Digital users are 'bouncers': most people view only 1-2 pages on a visit to a website from the thousands available; 3 is a lot of pages viewed. They are also promiscuous, with around $40 \%$ not coming back to a site. One-shots - one visit, one page are a very common user group. They behave like this because:

a. Of search engine searching (lists) and embedded links, which constantly enjoin them to cross-compare and always move on;

b. Of the provision of massive and changing digital choice;

c. There is so much 'rubbish' and irrelevance on the web, causing users to rapidly abort many searches;

d. Of their limited retrieval skills, on average 2.2 words are used per query and most people only ever look at the first page of Google results, when in fact you are commonly provided with thousands of pages;

e. They leave their memories in cyberspace, which means they forgot what they did previously and have to start all over again (often compounding any errors that were previously made);

f. This is a direct result of end-user checking - people are not used to evaluating material and certainly not as good as the librarians who used to make choices on their behalf;

(3) In information seeking terms digital users 'skitter' (moving rapidly along a surface, with frequent light contacts or changes of direction);

(4) And then there is multi-tasking - the digital user finds it more pleasurable to do several things at once rather than just one thing; they are constantly opening out new windows and connecting to several devices (phones, laptops, desktops, e-readers) and this inevitably results in briefer and lighter visits.

(5) Nobody dwells or does much reading, or certainly not what is traditionally thought to be reading in the online environment (that is reading whole document or chapter). A read can mean 10-15\% of a document. From the logs we learn that:

a. Only a few minutes is spent on a visit and 15 minutes in the Internet world is a very long time for a visit;

b. If it is an article they are interested in 3-4 minutes will be spent on it;

c. Shorter articles have a much bigger statistical chance of being viewed;

d. Abstracts, because of their brevity, the condensation they offer and navigational qualities have never been so popular; 
e. Digital users spend more time on visual pages/sites;

f. Users probably never wanted it 'all', there was a system in the past of batch processed delivery; they took it all because they had no choice; As in real life, the (information) snack/bite has replaced the three course meal (whole book/ article).

Digital users have been conditioned by emailing, text messaging, tweeting and PowerPoint to like/produce/want/need fast shots of information. Web designers and content providers thought digital consumers would knock on the front door and dwell when they got in. They don't!

(6) Digital users like things simple and quick and for this reason they avoid carefully-crafted discovery systems and advanced searching and prefer instead Google and Google Scholar; even the very top researchers do so.

\section{Information seeking in the mobile space}

In this part of the paper I will describe a comprehensive range of characteristics of mobile information use - volume and growth in use/users, type of mobile phone used, time period when used, geography of use and a batch of standard information seeking metrics. Where appropriate and relevant, mobile use is compared with desktop or fixed machine use, for which we also have data.

\subsection{Volume of use and growth}

Europeana currently (2013) attracts just over 155,000 mobile visitors per year who make more than a million page views. Mobile users are, therefore, a significant group already for Europeana in terms of numbers and volume of use, but the most significant statistic is that mobile numbers are growing around five times faster than that for 'fixed devices'. So although mobile device page views now (December 2012) account for nearly $5 \%$ of all views it is going to be a lot higher than that in 2013. To put mobile device use in context it is way bigger than that from social media users (people who come to Europeana from Facebook and the like), who account for just 1\% of page views, and growing at a fraction of the mobile rate.

\subsection{Country of use}

We can detect from the logs where the Europeana mobile traffic comes from and Germany produces the greatest amount of traffic, with more than 74,000 page views made during the six month period June to Dec 2012. Despite the distance and the fact that their digital cultural collections are obviously absent from Europeana, the USA come a strong second with over 63,000 views. In terms of per capita use then Netherlands $\left(3^{\text {rd }}\right)$ and Norway $\left(7^{\text {th }}\right)$ rank particularly highly. Some of the Netherland's use has to be discounted as it is the home of Europeana and many of its developers are mobile device users. In 2011 France was the biggest user by some margin, but now it lies at $4^{\text {th }}$, showing how dynamic the market it is. 


\subsection{Type of mobile device used}

Mobile use, at least as far as Europeana is concerned, is not smartphone but tablet use, and overwhelmingly the iPad. Nearly half (47\%) of all ,mobile' use during the last six months of 2012 comes from an iPad. If we include the iPhone (ranked third after the Android) then clearly Mac machines dominate mobile use of Europeana, accounting for close to $70 \%$ of all mobile use.

\subsection{When Europeana is visited}

The intensity of Europeana use, as expressed by page views, varies between the week and the weekend and at different times of the day as people shift between different contexts and personas, from the professional to the personal. Fixed machine use peaks in the late afternoons and on Wednesdays, whereas mobile phone usage peaks on Saturdays and late into the evening (around 11pm). Clearly, mobile devices have considerably widened access to Europeana at weekends and outside of traditional office hours.

\section{Comparative information seeking behaviour (mobile vs. fixed platforms)}

As we have heard mobile use is growing at a considerable rate and to understand the significance of this we need discover how mobile users search and how differently this is to the digital searching conducted on desktops and laptops that we have become used to in recent years. A comparison makes it very clear that there are considerable differences and that all the data points to the fact that visits from mobile devices are much shorter and less interactive than those from fixed platforms. Thus:

(1) A typical mobile visit at just over a minute - hardly a long time anyway, is actually 10 seconds (13\%) shorter than that for a fixed computer user;

(2) Mobile visits are less busy with fewer pages viewed - nearly 6 pages are viewed on average compared to nearly 9 pages for the fixed user (30\% less);

(3) Fewer searches are conducted, an average of 0.9 compared to 1.4 (36\% less) for fixed machines;

(4) Fewer records are viewed during a visit, 1.7 compared to 2.5 (32\% less).

On only one metric do mobiles score more highly and that is the time spent on page views. Mobile users spend on average more than twice as long per page, but this is only to be expected given the relatively slow performance of these devices some situations and locations; something, of course, which is changing as we write.

There are also big differences between mobile devices. A comparison of the performance of three popular mobile devices (Blackberry, iPhone and iPad), shows clearly that the behaviour of mobile Europeana users is heavily shaped by the kind of device they use. The limited screen real estate and slowness of the Blackberry is clearly a limiting factor for information seeking. Just look at the data: duration of visit (19.4 seconds), pages per visit (3.5), time per page (5.5 seconds), search page views per visit (0.4), queries per visit (0.3) and records viewed per visit (1.0). On the other hand, the tablet iPad generates usage 
metrics that are not hugely dissimilar from fixed machines and the iPhone performance falls somewhere between that of the Blackberry and iPad.

\section{Conclusions}

Four years ago Europeana was prescient in considering the mobile user in its development plans because mobiles are now a very fast growing market segment for Europeana and growing far faster than that for PCs. In fact mobile use grew fivefold during 2012. However it is tablets, rather than smartphones that are making the biggest splash. The iPad in particular has achieved a major breakthrough making the tablet (big touch-screen, un-encumbered by wires or peripheral devices) a popular platform where previous attempts have failed. It redefines the consumer 'personal computer' experience; in fact it is an 'inter-web' access device rather than a computational machine. The 'Pad' has changed the way we need to conceive the 'mobile' user. Where once there was a clear difference between mobile and PC the differentiation that is opening up is between Office and Personal. The Office is the desktop and laptop, keyboard and mouse, work and study, documents and organisation. The Personal is 'Pad and 'Phone, touch-sensitive and wireless, conversation and affiliation, in a word mercurial.

Mobile (smartphone and tablet) use is personal use, happens often in the evenings and on weekends; occurs in the home or 'anywhere but the office'. It is about consuming content not creating it. Social networking, courtesy of the mobile, may be creating contacts and networks but it is not building content as envisaged by those who suppose 'content is king' (typically publishers). In fact we can probably say that 'conversation is the king.'

Picking up on the fast food (information) analogy, mobile devices are providing the ultimate information take-away, with all the evidence showing that they are used for information bites and snacking - more bouncing, more new visits, shorter visits and simple and less productive searching are a feature of their use. More challengingly perhaps mobile users are more promiscuous.

So if smartphones and tablets have already become, or soon to become, the main platforms for accessing the Web, will this also mean that they will become the main platform for scholarly communication? We don't actually know the answer to that and we shall have to wait and see, but logic would seem to suggest that this will indeed be the case. Given that mobile searching differs quite markedly from fixed/office/library based searching are publishers (and libraries) ringing the changes on their websites? A quick, non-scientific trawl around publisher websites shows none really look like Europeana which has been adapting to mobile use for four years, or have its simplicity and visuals, but then maybe the aims and content of the sites are different. But, to be honest, most sites still look like they were designed for people doing their searching in their libraries, enjoying the fruits of the big deal. Opportunities for pay as you go are there but most publishers are charging far too much for an article and this will become very evident in the mobile marketplace of quick deals, cross comparison sites and micro-payments.

For librarians the mobile device is a much bigger challenge and one they might not fully meet. Relatively speaking the library's information universe has largely remained static when everyone else's has massively expanded, admittedly from a small base. Scholars' 
information horizons were once bound by the library but not anymore. Libraries might be seen as incomplete sources of information with users not trusting librarians to make the critical decisions on what is and what is not in the walled garden on their behalf. Librarians will need to develop good policies and practices to deal with a borderless information world and information consumed on the move or they risk being side-lined, but precisely what these policies and practices are are yet to be ascertained. But maybe a good start would be teaching information literacy using the smartphone or tablet, rather than library computer.

Finally, CIBER's most recent research project, an examination of trust and authority in the digital scholarly environment (CIBER, 2013b), adds more support for the belief that the information community is facing a paradigm shift on an enormous scale. The research shows that the young, equipped with their mobile devices, not only behave differently but think differently. Thus it was found that while senior researchers believe that trust in scholarly communications, something that libraries have a big stake in, was enhanced if the source was available in print, young researchers thought the very opposite; they could not believe anyone would think like that, for them the digital was the real.

\section{References}

Carr, N. (2011). The Shallows: What the Internet Is Doing to Our Brains. New York: W.W Norton. CIBER (2013a). Europeana 2012-2013: usage and performance update Europeana 2012-2013: usage and performance update [online]. CIBER Research [28.07.2013], http://ciber-research.eu/

CIBER (2013b). Trust and authority. CIBER Research [08.11.2013] http://ciber-research.eu/CIBER_ news-201309.html

Eddy, N. (2013). Mobile Device Users Move to Tablets, Smartphones for Web Access: MwC [online]. eWeek [28.07.2013], http://www.eweek.com/mobile/mobile-device-users-move-to-tabletssmartphones-for-web-access-mwc/

Nicholas, D. (2012). Information Seeking and Reading Behaviour of the Virtual Researcher [online]. LIBER 41 ${ }^{\text {st }}$ Annual Conference, 27-30 June 2012, Tartu, Estonia [28.07.2013], http://www.utlib. ee/liber2012/index.php?id=tartu

Nicholas, D.; Clark, D. (2012). Evidence of user behaviour: deep log analysis. In: M. Dobreva, A. O`Dwyer \& P.Feliciati (eds.) User studies for digital library development. London: Facet Publishing, 85-94.

Nicholas, D.; Rowlands, I. (2010). Virtual scholars: their characteristics and implications for librarians. Link, 11, 2-3.

Pew Internet (2013a). Smartphone ownership 2013 [online]. Pew Internet [28.07.2013], http://pewinternet.org/Reports/2013/Smartphone-Ownership-2013/Findings.aspx

Pew Internet (2013b). Tablet ownership 2013 [online]. Pew Internet [28.07.2013], http://pewinternet. org/Reports/2013/Tablet-Ownership-2013.aspx

Rowlands, I.; Nicholas, D.; Williams, P.; Huntington, P.; Fieldhouse, M.; Gunter, B.; Withey, R.; Jamali, H.R.; Dobrowolski, T.; Tenopir, C. (2008). The Google generation: the information behaviour of the researcher of the future, Aslib Proceedings, 60 (4), 290-310.

Srivastava, L. (2005). Mobile phones and the evolution of social behaviour. Behaviour \& Information Technology, 24(2), 111-129. 


\title{
Czasy się zmieniają (znowu!): drugi wielki zwrot cyfrowy do przestrzeni mobilnej
}

\begin{abstract}
Abstrakt
Cel: Zgodnie z ocenami przemysłu informacyjnego, urządzenia mobilne staną się wkrótce główną platformą dla przeszukiwania Internetu i czytania znalezionej w nim informacji, jednak nasza wiedza o tym jak miliony mobilnych konsumentów wykorzystują informację i jak różni się to od zachowań użytkowników komputerów osobistych jest niedoskonała. Artykuł ma wypełnić tę lukę.

Koncepcja/Metody badań: W tym celu wykorzystana została analiza logów Europeny, najważniejszego serwisu informacji o kulturze. Przebadano zachowania więcej niż 150000 mobilnych użytkowników zarejestrowane w okresie ponad roku oraz porównano je z zachowaniami użytkowników PC korzystających z tego samego serwisu w tym samym czasie. Analiza ta obejmowała: wielkość i wzrost wykorzystywania serwisu, wzorce czasu wykorzystywania, lokalizację geograficzna użytkowników oraz porównawcze wzorce zachowań zwiaanych z wyszukiwaiem informacji.

Wyniki i wnioski: Głównym ustaleniem było to, że użytkownicy mobilni są najszybciej rosnącą grupą i ich liczba będzie nadal rosła bardzo gwałtownie, a także to, że odwiedzanie przez nich serwisów internetowych bardzo różni się od tego, które podejmowane jest z platform stałych. Wizyty mobilne mogą być opisane jako informacyjnie "lite": zazwyczaj krótsze, mniej interaktywne, mniej treści jest przeglądanych w czasie pojedynczych odwiedzin. Korzystanie z serwisu przez użytkowników mobilnych przyjmuje wzory bliższe raczej zachowaniom związanym z relacjami społecznymi niż z poszukiwaniem informacji dla celów zawodowych, z charakterystycznym najbardziej intensywnym odwiedzaniem serwisu w późnych godzinach wieczornych i w weekendy. Duże okazało się zróżnicowanie zachowań użytkowników korzystających z różnych urządzeń mobilnych, przy czym poszukiwanie informacji przez użytkowników iPadów oraz PC i laptopów było podobne, bardzo natomiast różniło się od niego zachowanie użytkowników smartfonów. Badanie potwierdziło, że zachowanie związane z poszukiwaniem informacji jest zależne od wykorzystywanej platform, a najnowsze platform całkowicie je znowu zmieniają. Serwisy internetowe, wydawcy i e-bibliotekarze będą musieli się do tego dostosować.

Oryginalność/Wartość poznawcza: Omówione badania są jednym z najszerzej zakrojonych studiów dotyczących zachowań informacyjnych użytkowników korzystających z urządzeń mobilnych, jakich wyniki dotychczas opublikowano. Nie prowadzono także dotąd tego typu badań nad mobilnymi użytkownikami informacji o kulturze.
\end{abstract}

Słowa kluczowe Analiza logów. Europeana. Użytkownicy mobilni. Użytkownicy PC. Wyszukiwanie informacji. Zachowania informacyjne.

DAVID NICHOLAS is a Director and founder of the internationally renowned CIBER Research Group. The group is perhaps best known for its deep log analysis techniques for monitoring online behaviours, especially in regard to the Google Generation. He is also a professor at the University of Tennessee and Northumbria University (USA). Previously Professor Nicholas was Head of the Department of Information Studies at University College London for seven years (2004-2011) and prior to that Head of the Department of Information Science at City University (1997-2003). His interests include use and seeking behaviour in virtual spaces, the digital consumer, the virtual scholar, mobile information (information on-the-go), e-books, e-journal usage; the evaluation of digital platforms and user needs analysis. Professor Nicholas has been principal investigator on over 60 research projects, and published more than 500 peer evaluated papers and 12 books. The most important recent publications: $D . N i$ cholas, D. Clark: Reading' in the digital environment. Learned Publishing, 21(2) April 2012, 51-56; D. Nicholas, D. Clark \& I. Rowlands: Information on the go: case study of Europeana mobile users. Journal of the American Society of Information Science 64(7), 2013, 1311-1322; D. Nicholas, I. Rowlands, A. Watkinson, D. Brown, H. Jamali: Digital repositories ten-years on: what do scientific researchers think of them and how do they use them? Learned Publishing 2012, 25, 195-206; D. Nicholas: Dis-intermediated, decoupled and down: future of the library profession. CILIP Update, March 2012, 29-31. 